\title{
STRUCTURE OF TRICHOMATOUS NECTARIES IN FLOWERS OF LONICERA KAMTSCHATICA (SEVAST.) POJARK.
}

\author{
Elżbieta Weryszko-Chmielewska, Małgorzata Bożek
}

\author{
Department of Botany, University of Life Sciences in Lublin, Akademicka 15, 20-950 Lublin, Poland \\ e-mail: elzbieta.weryszko@up.lublin.pl
}

Received: 11.03.2008

$\mathrm{Su} \mathrm{m} \mathrm{m} \mathrm{a} \mathrm{r} \mathrm{y}$

The structure of the floral nectaries of Lonicera kamtschatica was examined using light microscopy, scanning electron microscopy and transmission electron microscopy. Nectariferous tissues are located in the lower portion of the corolla tube. It was found that the secretory tissue of the nectary was composed of two layers of epidermal formations: short papillae and about $3 x$ longer unicellular trichomes. They cover the adaxial surface of a small spur.

Nectar secretion takes place through the apical portion of the trichomes and papillae. The cell wall of the upper part of the trichome has protuberances participating in nectar transfer to the subcuticular space which reaches large dimensions. The lateral walls of the trichomes are saturated with cutin. The papillae have much thicker walls than the trichomes. In the papillae, there are no wall protuberances. Less secretion accumulates in the subcuticular cavities of the papillae than in the trichomes.

Key words: Lonicera kamtschatica, flowers, nectary, secretory trichomes, papillae, micromorphology, ultrastructure

\section{INTRODUCTION}

About 200 species belong to the genus Lonicera (Caprifoliaceae) (S zweykowska and Szweykowski, 2003). Among them, there are frequently planted ornamental shrubs with decorative leaves, flowers and fruits. However, Lonicera kamtschatica, originating from Eastern Asia, is grown for its edible fruits which have medicinal and dietetic values ( $\mathrm{K}$ a w e c k i, 2005).

In the conditions of south-eastern Poland, L. kamtschatica flowers from the third decade of April until the middle of May (B o ż e k and W i e n i a r s k a, 2006). Its fruits, pseudo-berries, ripen at the turn of May and June. Two flowers grow on a stalk and, as a result of that, berries also develop in pairs. Sympetalous flowers have a light yellow, five-lobed corolla with a long tube. A pair of flowers is accompanied by two bracts and four bracteoles fused with the inferior ovary ( $\mathrm{B} \mathrm{u} \mathrm{g} \mathrm{a} \nmid \mathrm{a}$, 2000).

Flowers of L. kamtschatica are protandric, with five stamens which mature successively. The flower life span is 3-5 days (B o ż e k and Wi e n i a r s k a, 2006; $\mathrm{B}$ o ż e k, 2007). The nectary in flowers of L. kamtschatica is located in the lower part of the corolla tube where nectar is secreted in abundance. The nectar sugar content of different varieties of $L$. kamtschatica stands at $33-36 \%$ (B ożek and Wieniarska, 2006). The ultrastructure of the floral nectaries of $L$. japonica has been studied earlier by $\mathrm{Fahn}$ and $\mathrm{Rachmilevitz}$ (1970, 1975).

The aim of the study was to determine the distribution and structure of different types of glandular trichomes of the nectary of L. kamtschatica, which have not been studied in this species so far.

\section{MATERIALS AND METHODS}

Flowers of honeyberry (Lonicera kamtschatica (Sevast.) Pojark. syn. L. caerulea L. var. kamtschatica Sevast.) cv. Atut were collected from shrubs grown in Lublin at the Felin Experimental Farm of the University of Life Sciences.

The examination was carried out using light microscopy (LM), scanning electron microscopy (SEM) and transmission electron microscopy (TEM). Under the light microscope, the structure of the glandular epidermis of the nectary was analysed at different flower development stages: closed bud, on the first day of anthesis and at the petal fall stage (the fifth day of anthesis). Glandular formations of the nectary epidermis were examined on the first day of anthesis using SEM and TEM.

The cut longitudinal fragments of the corolla including the nectary surface were observed under a stere- 
oscope microscope. The longitudinal sections were made from fresh fragments of a flower with the nectary by means of a blade.

SEM. The fragments of the lower portion of the corolla were fixed in $2 \%$ glutaraldehyde with $2.5 \%$ paraformaldehyde in $0.075 \mathrm{M}$ phosphate buffer ( $\mathrm{pH} 6.8)$ for $12 \mathrm{~h}$ at a temperature of $4^{\circ} \mathrm{C}$. After dehydration in ethanol series and acetone, the samples were dried at critical point in liquid $\mathrm{CO}_{2}$. Using the CS 100 sputter coater, they were coated with gold and observed under the BS-300 Tesla scanning electron microscope.

LM. Semithin sections $0.5-0.7 \mu \mathrm{m}$ thick were made after fixing and embedding the dehydrated material in epoxy resin following the method described for TEM. The pieces were stained with methylene blue with $1 \%$ azur II in a $1 \%$ solution of sodium tetraborate.

TEM. Plant material was fixed in $2.5 \%$ glutaraldehyde and $2 \%$ paraformaldehyde in $0.05 \mathrm{M}$ cacodylate buffer for 3 hours. After post-fixation in 2\% osmium tetroxide and dehydration in an ethanol series, the samples were embedded in Spur's epoxy resin. Ultrathin sections $(60 \mathrm{~nm})$ were cut in the Reichert Ultracut $\mathrm{S}$ microtome. Next, the material was treated with an $8 \%$ solution of uranyl acetate and saturated solution of lead citrate. Observations were made using the BS-500 Tesla transmission electron microscope.

\section{RESULTS}

The corolla of Lonicera kamtschatica flowers is about $15 \mathrm{~mm}$ long. At the base of the corolla tube ( $8 \mathrm{~mm}$ long), a one-sided bulge is found forming a rounded spur (Figs 1 A, B; 2 A, B). The inside part of the spur is occupied by the nectary producing numerous glandular trichomes (Figs 1 B-G; 2 A-D). On the remaining adaxial part of the epidermis of the corolla tube, long non-glandular trichomes are found at places, likewise on the whole abaxial surface of the corolla (Figs $1 \mathrm{~B}$; $2 \mathrm{~A}-\mathrm{C})$. The trichomes covering the nectary surface grow in large density inside the spur (Figs $1 \mathrm{E} ; 2 \mathrm{~A}, \mathrm{~B}$ ) and they form a secretory zone located in the corolla tube up to $2 \mathrm{~mm}$ above the spur bottom (Figs $1 \mathrm{C}, \mathrm{D} ; 2 \mathrm{C}, \mathrm{D}$ ).

The secretory surface of the nectary is composed of two layers of epidermal formations of different height. The upper layer is made up of unicellular glandular trichomes, and the lower layer of much smaller papillae, being different-shaped protrusions of the epidermal cells (Figs 1 F, G; 2 C, D; 3 A-D). Such differentiation of the glandular structures was observed both in closed buds with the length of $4.5 \mathrm{~mm}$ and in the nectaries of flowers at the petal fall stage.

Cells of the subepidermal tissues of the nectary were thin-walled and quite densely packed (Figs $5 \mathrm{~A}$, B, F). On the first day of anthesis, they were marked by a large degree of vacuolisation and more elongated plastids (Fig. $6 \mathrm{C}$ ) than those found in the trichomes
(Fig. 5 D). Vascular bundles running in the vicinity to the nectary were composed of xylem and phloem elements (Fig. 5 B).

Nectar secretion in flowers of Lonicera kamtschatica starts already at the loose bud stage. Nectar production is abundant throughout the whole flowering period. Nectar accumulates in the corolla tube up to $1 / 2$ of its height.

\section{Secretory trichomes}

The nectar-secreting trichomes are oval or capitate in shape. Located in the upper portions of the nectary, they are most frequently arch-like curved into the inside of the spur (Figs 1 F, G; 2 C, D). Their length is within the range of $70-100 \mu \mathrm{m}$. The surface of the cuticle covering the trichomes is characterised by verrucose sculpture or it is composed of short striae (Figs 3 A-C).

On the first day of anthesis, we observed bulges on the walls of some trichomes, formed by the detached cuticle under which nectar accumulated (Figs 3 B-D). In the trichomes being at the nectar secretion phase (1st5 th day of anthesis), the detached cuticle, forming at the apex or the sides of the trichome a subcuticular space in which nectar was accumulated, was visible under the light microscope (Figs 4 A-D; 6 A, B). The thickness of the cuticular layer was very different (Figs 5 D, E; $6 \mathrm{~A}, \mathrm{D})$. The places of cuticle thickenings corresponded to wartlike outgrowths visible in SEM. The lateral lower-located parts of the trichome walls are stained in the semithin sections similarly to the cuticular layer, which suggests that they are strongly cutinised (Fig. $6 \mathrm{~A}, \mathrm{~B}$, D). The absence of outer bulges at the apex of some trichomes may prove their asynchronous maturation and nectar secretion.

The cell wall of the secretory trichomes is characterised by the presence of a large secondary layer with protuberances, typical for transfer cells. In some trichomes, wall fragments were also observed, devoid of protuberances (Figs 5 F, 6 A).

The secretory trichomes contain large spherical nuclei, numerous small plastids and dense cytoplasm, poorly vacuolised at the beginning of flowering (Figs $5 \mathrm{G} ; 6 \mathrm{~A}, \mathrm{~B}, \mathrm{D})$ and separated by many large vacuoles in the successive days of flower life (Figs 4 A-D). The cell nucleus was most frequently located centrally (Figs $4 \mathrm{C}, 5 \mathrm{G})$.

Under the transmission electron microscope, electron-dense cytoplasm and numerous small vacuoles were observed in the trichomes of the nectaries of freshly opened flowers of L. kamtschatica (Fig. 7 A). In the cytoplasm, numerous plastids, mitochondria, Golgi bodies, ER tubules and ribosomes were found. The secondary wall protuberances, well developed on most of the area of the wall surface, were surrounded by clear plasmalemma (Figs 7 B, C; 8 A-C). The cuticle layer of uneven thickness exhibited undulation. The detachment of the cuticle from the cell wall started both at the apex 

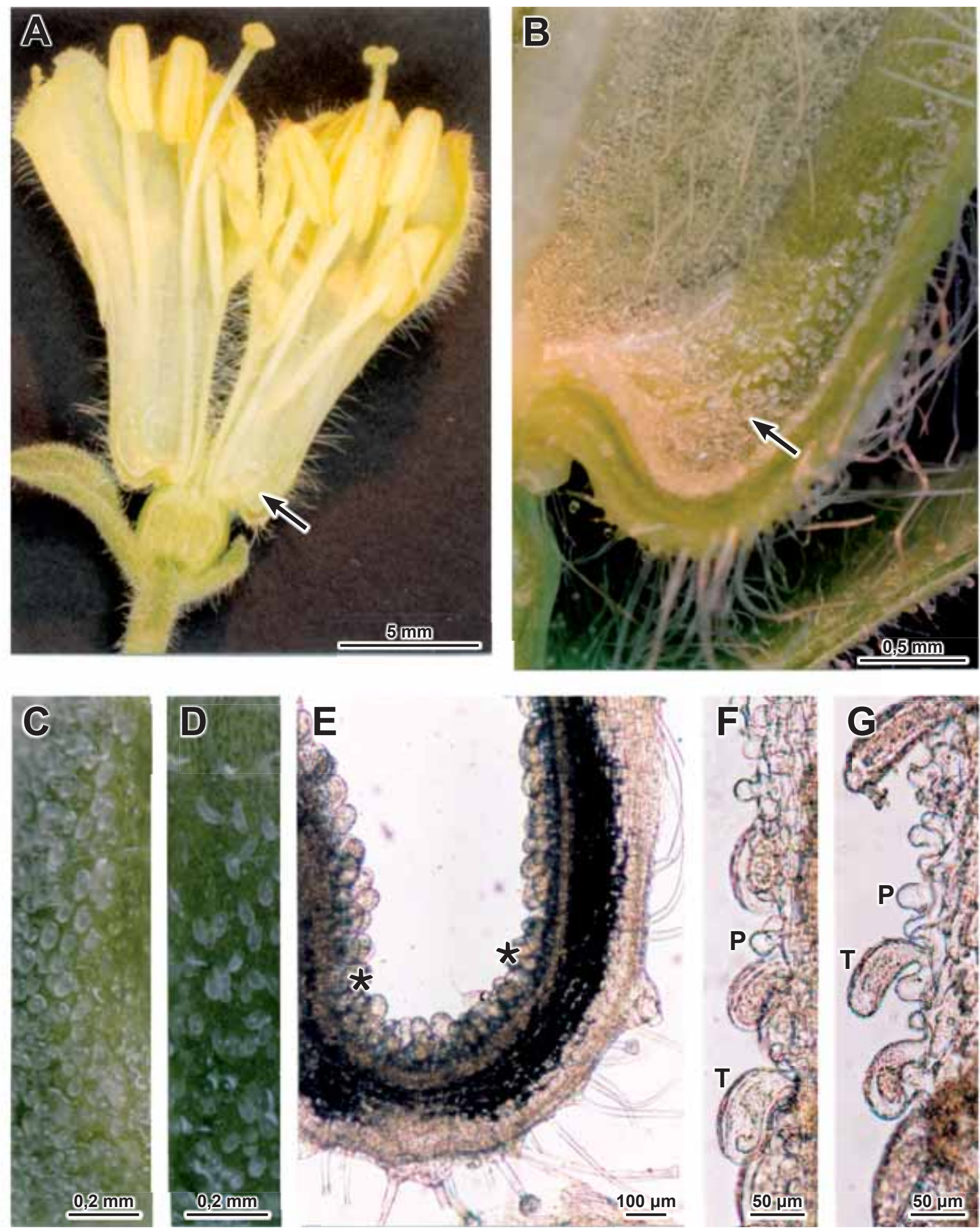

Fig. 1. Fragments of Lonicera kamtschatica flowers with secretory tissue of the nectary, located inside the spur (arrows). A. Longitudinal section of two flowers growing on one stalk; B. Fragment of the spur with secretory trichomes of the nectary; C, D. Shining secretory trichomes of the nectary; E. Densely packed glandular trichomes (asterisks) on the longitudinal section of the spur; F, G. Secretory trichomes $(\mathrm{T})$ and papillae $(\mathrm{P})$ of the nectary. 

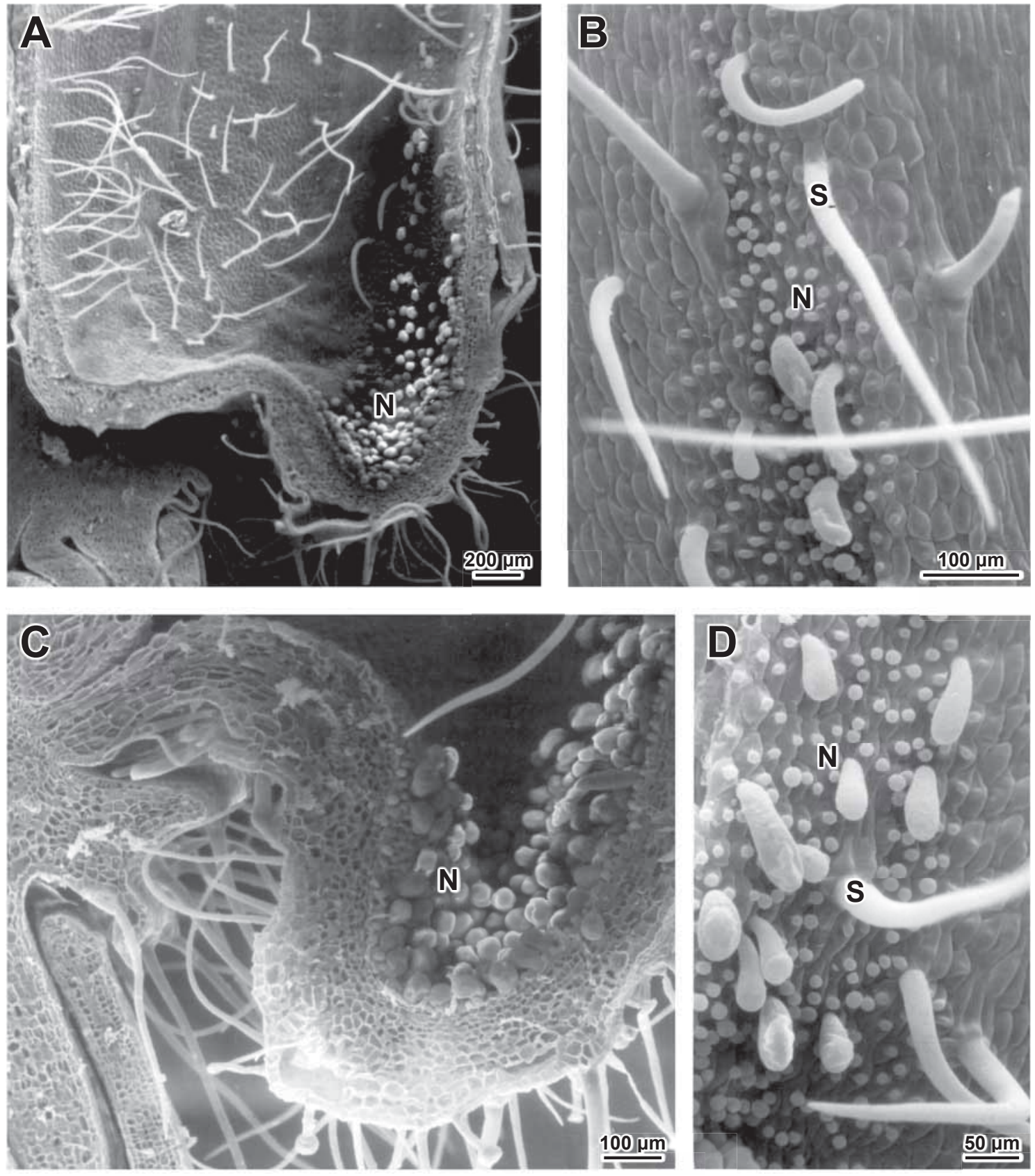

Fig. 2. Fragments of the internal surface of the corolla tube with secretory trichomes and papillae of the nectary (SEM). A, B. The lower portion of the corolla with the spur in which the nectary is situated; C, D. Secretory formations of the nectary $(\mathrm{N})$ and non-glandular secretory (S) on the corolla tube surface. 

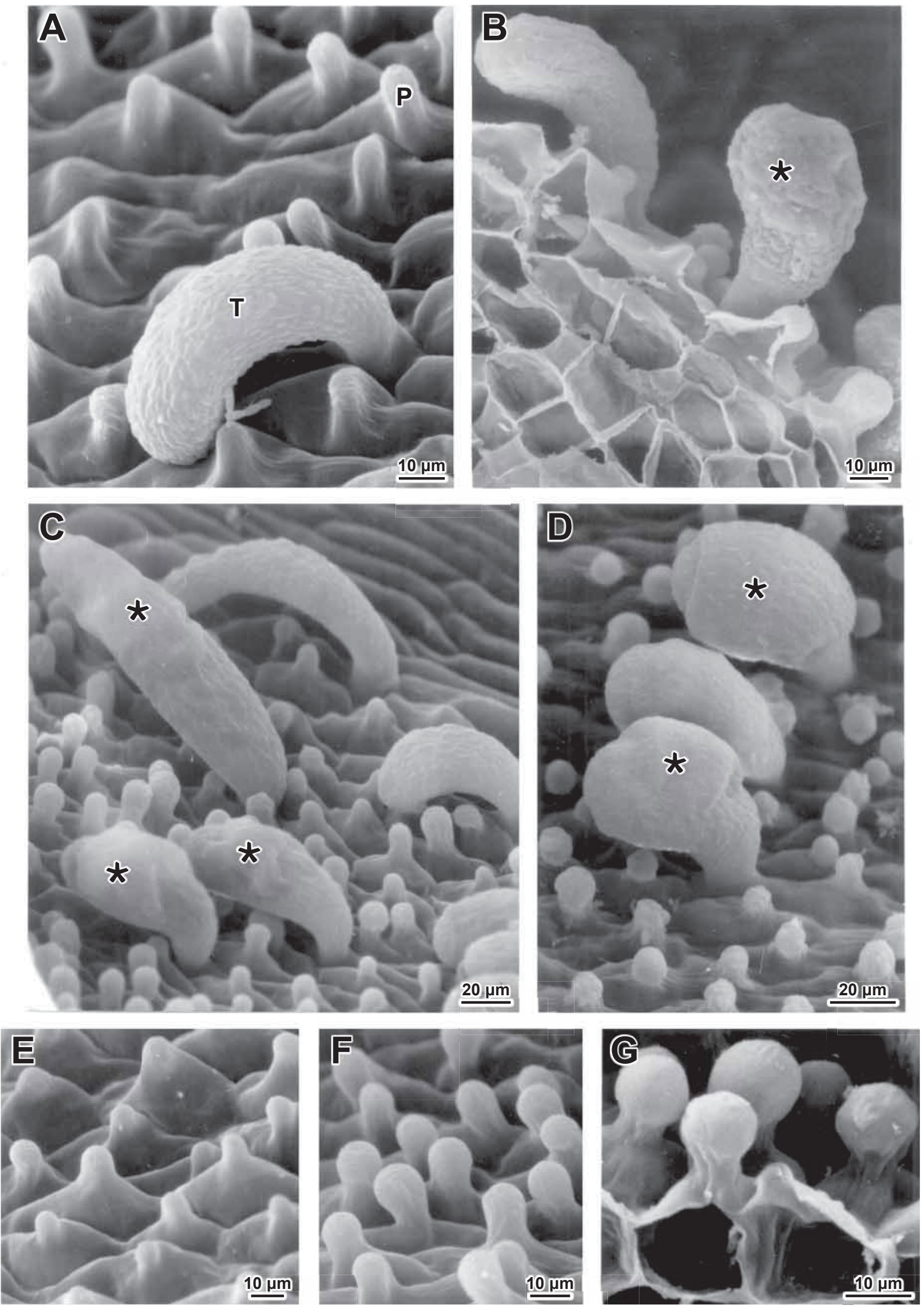

Fig. 3. Fragments of the nectary secretory epidermis with trichomes (T) and papillae (P) (SEM). A. Secretory trichomes and papillae with visible wall ornamentation; B, C, D. In some trichomes (asterisks), visible are swollen bulges which form subcuticular cavities containing the secretion; E, F, G. Different shaped and sized papillae. 

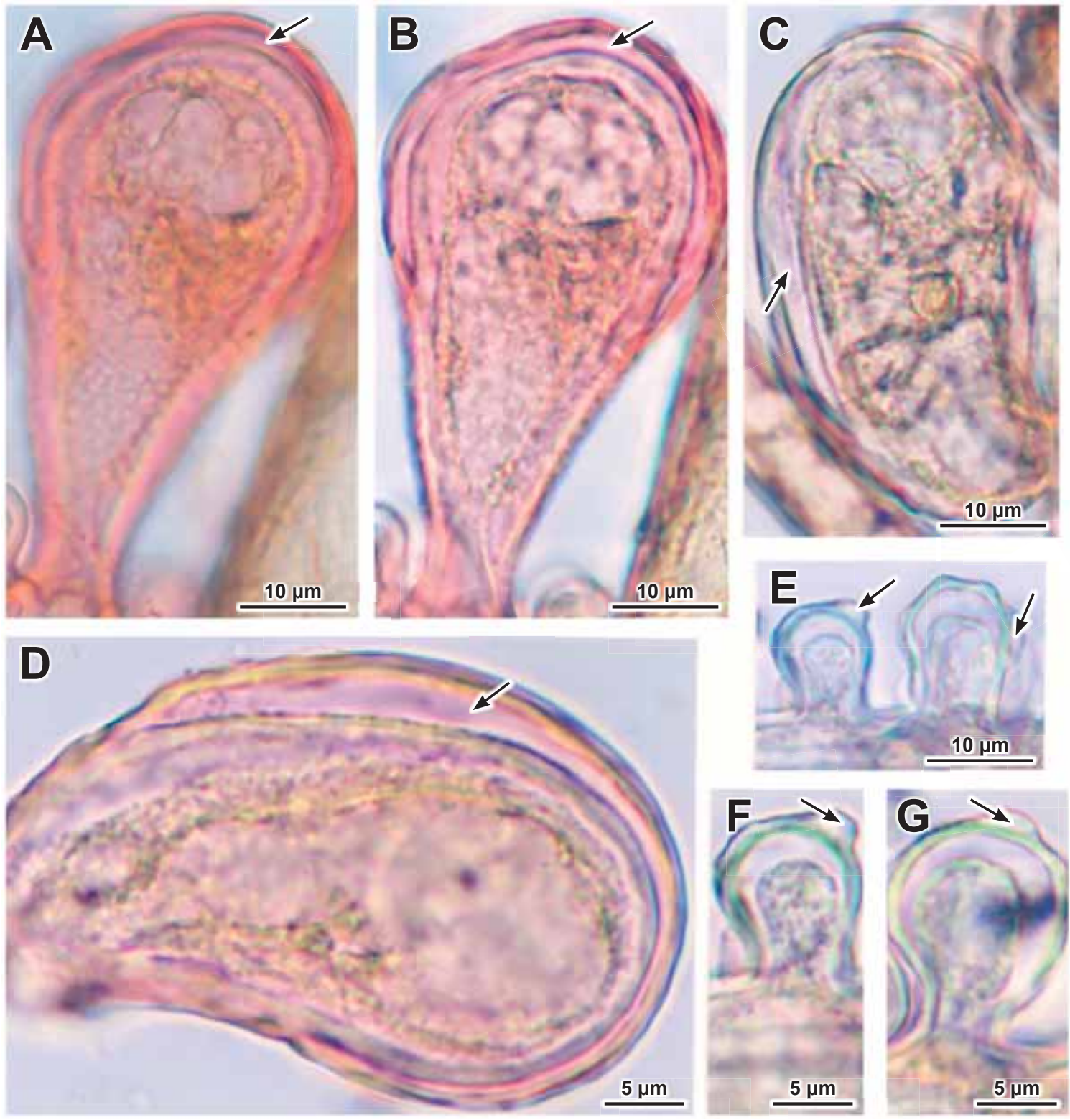

Fig. 4. Trichomes and papillae of the nectary with visible subcuticular spaces (arrows) in which nectar is accumulated (LM). A, B, C, D. Secretory trichomes; E, F, G. Secretory papillae. 

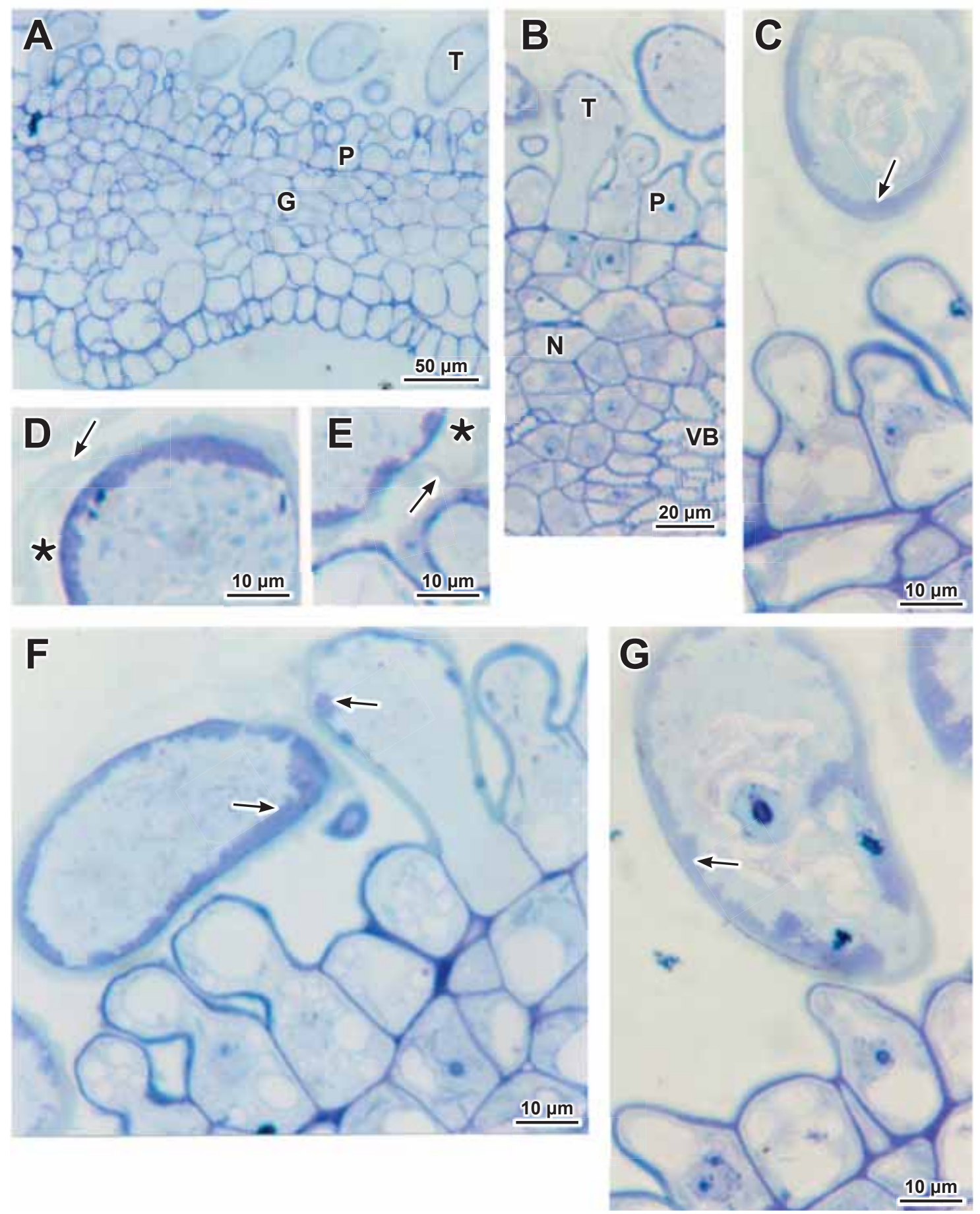

Fig. 5. Fragments of cross sections of the corolla tube of $L$. kamtschatica with nectar-secreting tissue (LM, semithin sections). A. The secretory layer of the nectary is made up of trichomes $(\mathrm{T})$ and papillae $(\mathrm{P})$, glandular tissue is visible beneath $(\mathrm{G})$. B. Tissues of the nectary $(\mathrm{N})$ are supplied by adjacent vascular bundles $(\mathrm{VB}) ; \mathbf{C}, \mathbf{F}, \mathbf{G}$. Secretory papillae and trichomes exhibit different degrees of vacuolisation. In the trichomes, secondary wall protuberances are visible (arrows); D, E. Fragments of trichome cell walls with the detached cuticle and visible subcuticular space (arrows). 

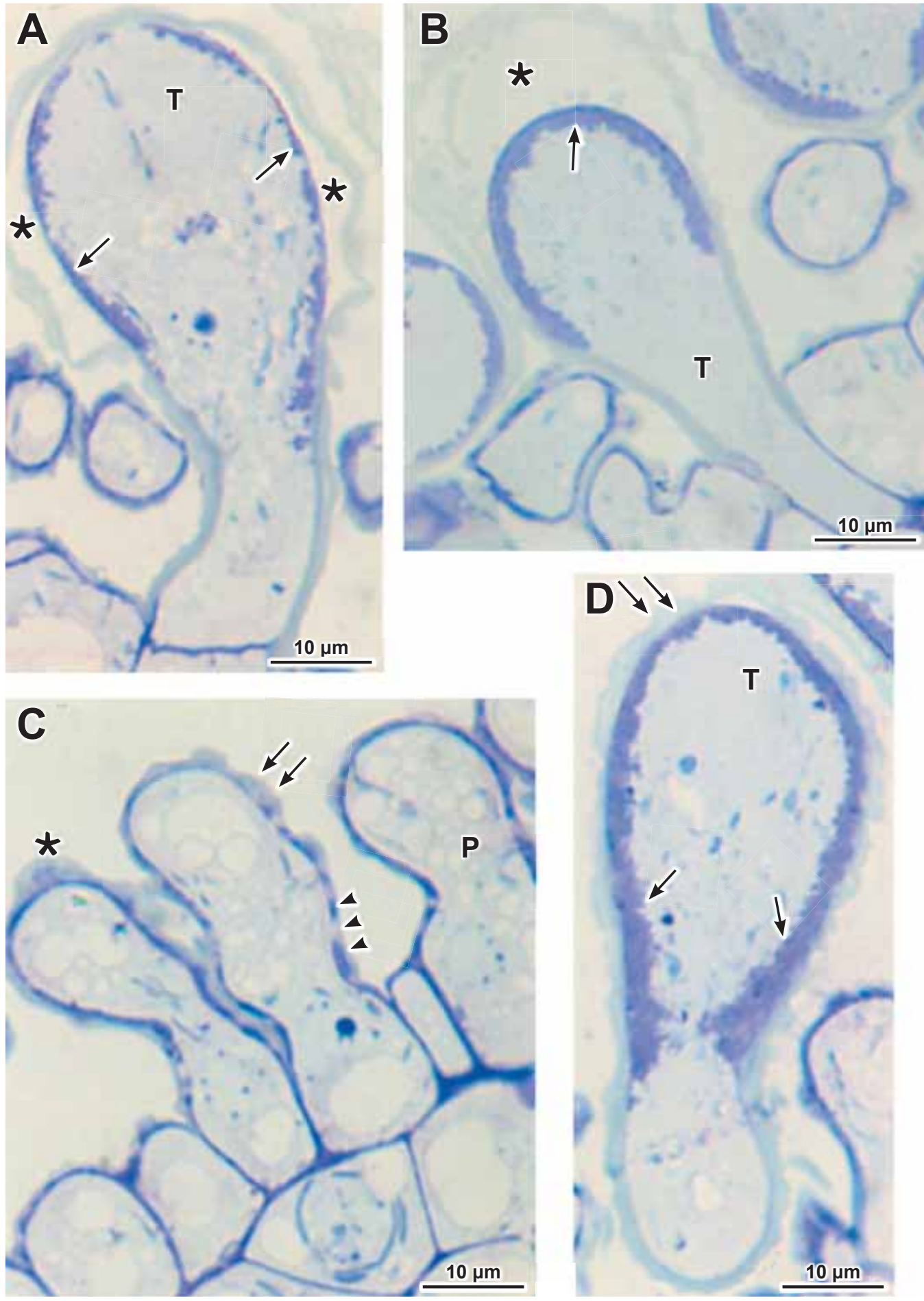

Fig. 6. Trichomes (T) and papillae (P) from the secretory layer of the L. kamtschatica nectary (LM). A. A trichome with poorly developed wall protuberances (arrows) and subcuticular space visible in the upper part (asterisks); $\mathbf{B}$. Large subcuticular space formed in the apical portion of the trichome (asterisk) and well-developed secondary wall (arrow); C. Papillae with cell wall fragments exhibiting different degrees of staining (arrowheads) and thickened cuticle at places (double arrows) as well as detached (asterisk) cuticle; D. Fragment of a trichome with well-developed secondary wall (arrows) and cuticle of uneven thickness (double arrows). 

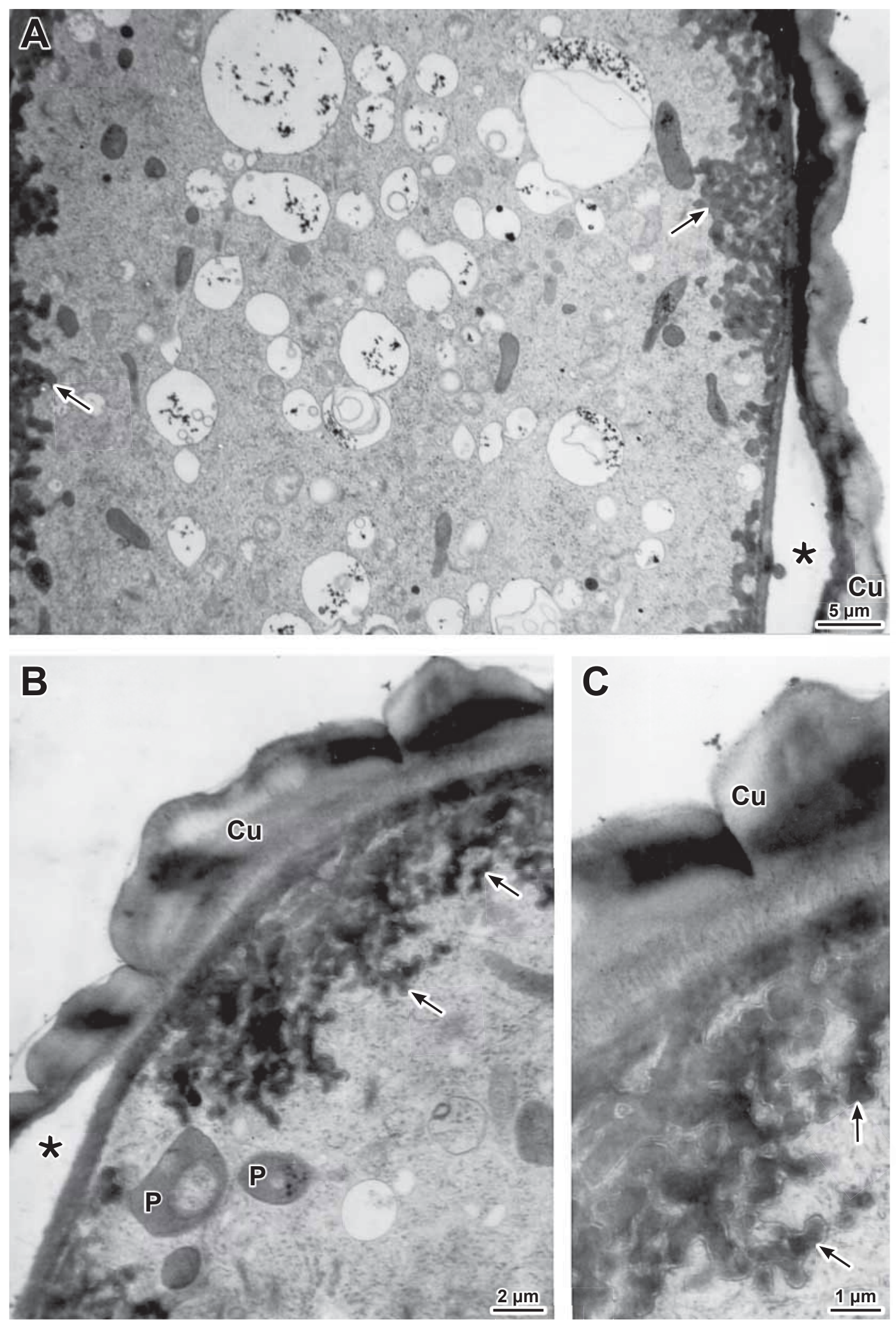

Fig. 7. Fragments of secretory trichomes of the L. kamtschatica nectary (TEM). A. The subapical portion of a trichome with visible secondary wall protuberances (arrows), detached cuticle $(\mathrm{Cu})$ and subcuticular space (asterisk); B, C. Apical fragments of a trichome with cuticle of uneven thickness $(\mathrm{Cu})$, wall protuberances (arrows) and plastids $(\mathrm{P})$, located near the cell wall. 

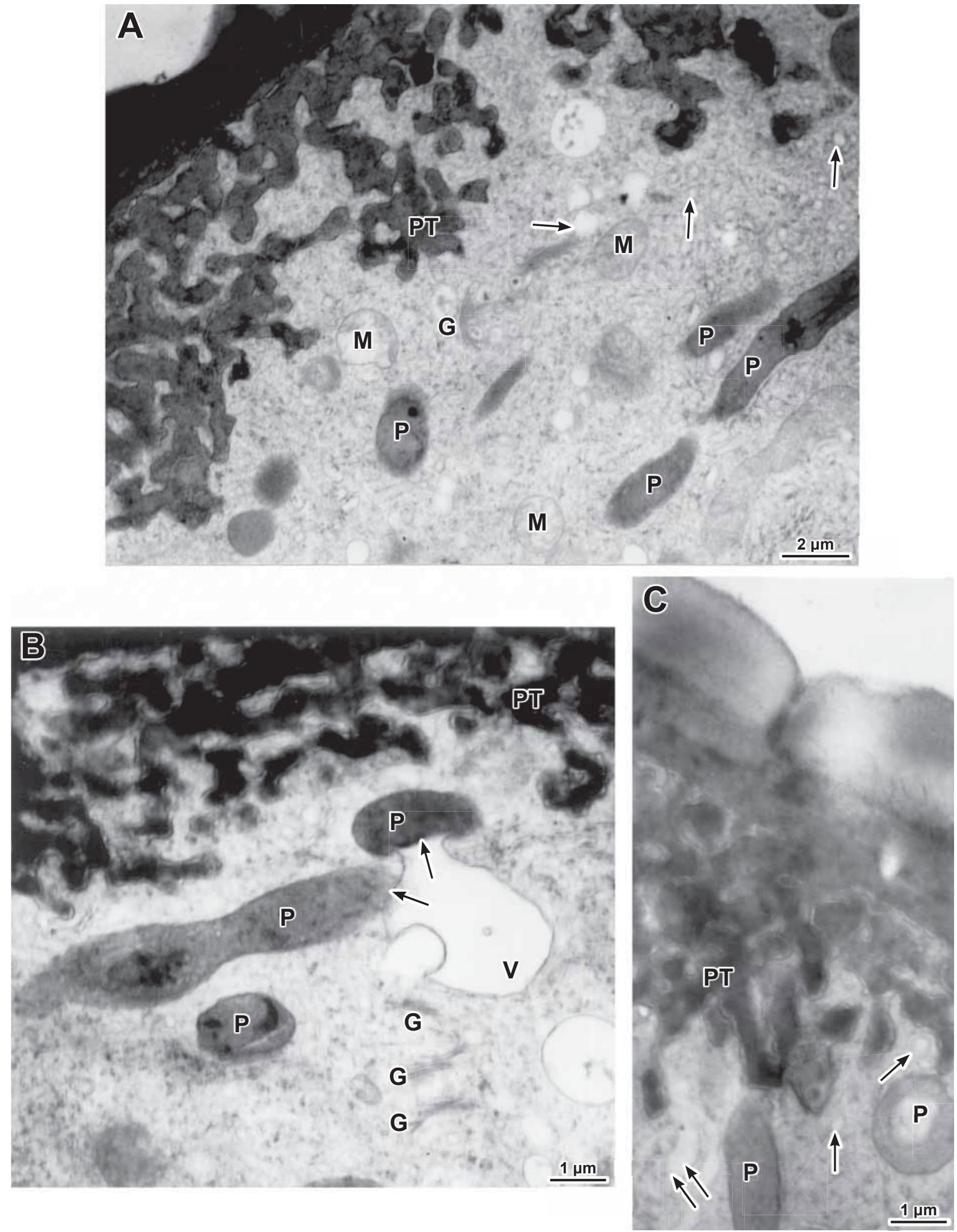

Fig. 8. Fragments of the apical portion of secretory trichomes of the nectary (TEM). A. Near the cell wall with protuberances (PT), visible are plastids (P), mitochondria (M), Golgi bodies $(\mathrm{G})$ and numerous secretory vesicles (arrows); B. Fragment of a cell with wall protuberances (PT), pleomorphic plastids (P), Golgi bodies $(\mathrm{G})$, ER profiles and ribosomes, some plastids are in close contact (arrows) with vacuole (V); C. Plastids (P), ER cisternae (double arrows) and secretory vesicles (arrows) in close contact with cell wall protuberances (PT). 

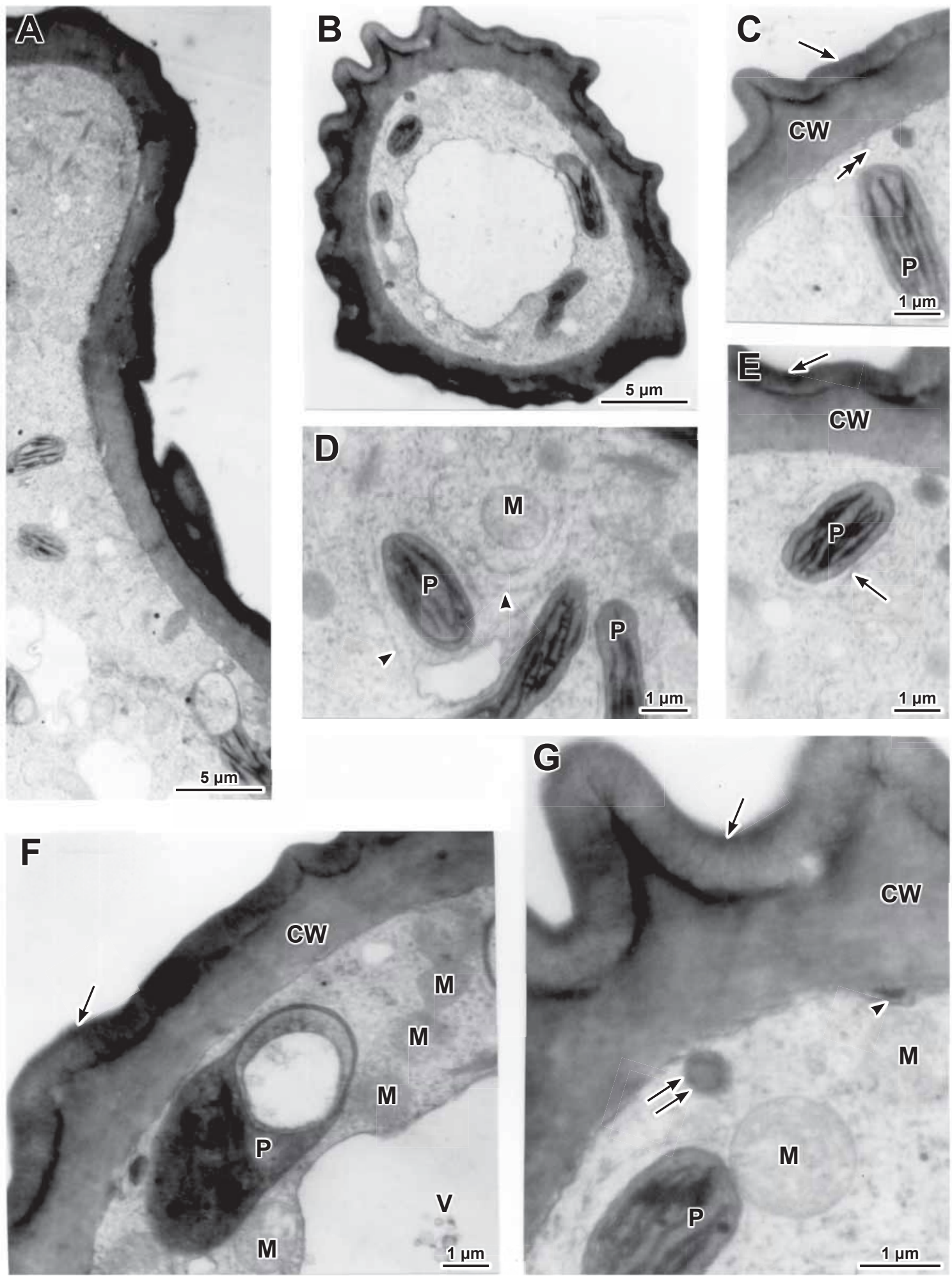

Fig. 9. Fragments of secretory papillae of the L. kamtschatica nectary (TEM). A. Longitudinal section of papilla; B. Cross section of papilla; C, D, E, F. Fragments of papillae cells: visible cell wall (CW), cuticle (arrow), vacuole (V), chloroplasts (P), mitochondria (M), ER tubules surrounding chloroplasts and mitochondria (arrowheads) as well as secretory vesicles in the vicinity of the plasmalemma (double arrows); G. Fragment of a cell wall (CW) with the cuticle (arrow) in which the microchannels are visible and the cytoplasm with a chloroplast (P), mitochondria (M), electron-dense substance near the plasmalemma (double arrows) and in the periplasmatic space (arrowhead). 
(Fig. 7 B) and in the lateral parts of the trichomes (Fig. 7 A). This process was preceded by the formation of numerous microchannels in the boundary region between the cell wall and the cuticle (Fig. $7 \mathrm{C}$ ).

The pleomorphic, often strongly elongated, plastids were marked by the electron-dense stroma in which tubules with osmiophilic material were irregularly distributed (Figs 7 B; 8 A, B). Many plastids were situated in close vicinity to the cell wall (Figs 7 B; 8 B, C). Some plastids were surrounded by rough and smooth ER tubules as well as numerous secretory vesicles (Figs 8 A-C). Plastids remaining in close contact with the vacuoles were also observed (Fig. 8 B). Near the wall protuberances, numerous ER tubules and cisternae as well as secretory vesicles also occurred (Figs $7 \mathrm{~B}, \mathrm{C} ; 8 \mathrm{~A}-\mathrm{C}$ ). In the peripheral part of the cytoplasm, Golgi bodies were clustered together (Figs $8 \mathrm{~A}, \mathrm{~B}$ ), whereas numerous mitochondria were distributed both in the central and peripheral part of the cytoplasm (Figs 7 A; 8 A).

\section{Secretory papillae}

In the nectaries of L. kamtschatica, the papillae form outgrowths, conical or spherical at the top, of the secretory epidermis cells, which are 15-35 $\mu \mathrm{m}$ long. In its upper part, the surface of the papillae is characterised by irregular bulges, and beneath the apex it is striated or smooth (Figs $3 \mathrm{~A}-\mathrm{G}$ ). The observed bulges are formed by the cuticle detached from the cell wall at the places of secretion accumulation or they can be thickened cuticle fragments (Figs $3 \mathrm{G} ; 4 \mathrm{E}-\mathrm{G} ; 6 \mathrm{C}$ ). In some papillae, wall parts with the predominance of cellulose occurred alternately with strongly cutinised fragments (Fig. $6 \mathrm{C}$ ). At the full anthesis stage, the papillae exhibited a large degree of vacuolisation, and in many cases large vacuoles were situated in their apical portion (Figs $5 \mathrm{C}, \mathrm{F}, \mathrm{G}$ ). The nuclei were centrally located in the cells. Both in the papillae and glandular trichomes, the nucleus and cytoplasm were characterised by a similar degree of staining (Figs $5 \mathrm{C}, \mathrm{G}$ ).

The examination performed using transmission electron microscopy revealed that the cell wall of the papillae had a large thickness and showed numerous folds (Figs 9 A, B, C, D, F, G). On its surface, folded cuticle also occurs in which microchannels are visible (Fig. 9 G). In the electron-dense cytoplasm, numerous chloroplasts, mitochondria, Golgi structures, ER profiles, secretory vesicles and ribosomes were present. The pleomorphic plastids were marked by the large electron density stroma containing irregularly distributed thylakoids with the osmiophilic substance content (Figs 9 A-G). In some plastids, large bright regions were observed with fibrous content (Figs 9 A, F). The mitochondria with well-developed cristae formed clusters in many places and they were located in close vicinity to the plastids (Figs 9 A, B, D, F, G). The smooth and rough ER tubules surrounded the plastids and were arranged around some mitochondria (Fig. 9 D). The secretory vesicles with an electron-dense content were often noted in close contact with the plasmalemma (Figs 9 C, E-G), and the osmophilic secretion was also found between the plasmalemma and cell wall in the periplasmatic space (Fig. 9 G).

\section{DISCUSSION}

The nectary found in the spur of the corolla of Lonicera kamtschatica, according to the classification of S c h m id (1988) and B e rnard ello (2007), can be included in petal or corolla nectaries. Such nectary type is philogenetically older than nectaries found on internal flower parts (F a h n, 1953). Taking into account the histological structure and mode of nectar secretion, the nectaries of Lonicera should be classified in the group of trichomatous nectaries distinguished by Voge 1 (1977). Among the types mentioned by S mets (1986): nectaria caduca, nectaria persistentia and nectaria trichomalia, the latter includes the floral nectaries of Lonicera. Due to the secretion of nectar in the tubular corolla and its accumulation in the place of production, Pacini and Nepi (2007) described the mode of offering nectar to insects by Lonicera japonica flowers as primary presentation. Our study demonstrates that the same mode of presentation is found in L. kamtschatica.

The secretory tissue of the nectary of L. kamtschatica is composed of two layers: low papillae (up to $35 \mu \mathrm{m}$ high) formed from almost every epidermal cell and much higher (do $100 \mu \mathrm{m}$ ) unicellular trichomes, growing less frequently, separated by 3-6 papillae. Nectar is transferred through the cell wall in the upper or lateral dilated portion of the trichomes and accumulates subcuticularly. The cuticle in this region gradually becomes detached from the cell wall forming a large-sized secretory cavity. After the secretion is accumulated, the cuticle of uneven thickness probably releases nectar droplets in thin places. Smaller protrusions of the cuticle were observed on the last day of anthesis. F a h n and R a c h m i le vit z (1970) also observed that in L. japonica, after the end of nectar secretion, the subcuticular space was reduced and the cuticle adhered to the cell wall again. Esau (1973) reports that in glandular hairs the swollen and breaking cuticle sometimes regenerates and the secretion accumulates again.

It seems that the secretion of large amounts of nectar in L. kamtschatica takes places primarily through the unicellular trichomes, at the apex of which large subcuticular spaces are formed in which nectar is accumulated. But the papillae probably produce much less secretion accumulating in very small secretory cavities at their apex and permeating to the surface through the microchannels occurring in the cuticle. In the case of the papillae, the 
secretion is probably also nectar since, as a result of the absence of colour reaction after treatment with Sudan III, the presence of lipid compounds in it was excluded.

The secretory trichomes in L. kamtschatica function asynchronously. Apart from trichomes with the swollen apical part and detached cuticle, trichomes without cuticle bulges were found. A similar mode of nectar secretion was observed in L. japonicum by $\mathrm{F}$ a h $\mathrm{n}$ and Rachmilevitz (1970) as well as Fahn (1979).

The unicellular trichomes of the nectaries of L. kamtschatica had a thickened, in its upper part, strongly staining secondary cell wall with visible protuberances, typical for transfer cells. The occurrence of well-developed wall ingrowths in the walls of the nectarsecreting hairs of $L$. japonica has been earlier observed by Fahn and R a ch milevitz $(1970,1975)$. These authors found the presence of numerous vesicles being released from the Golgi structures and swollen edges of ER. These vesicles occurred in close vicinity to the wall protuberances, and some of them were fused with the plasmalemma.

It is known from studies of other authors that wall protuberances of transfer cells are formed from cellulose and pectic polysaccharides ( G unning and Pate, 1974). How ever, Dahiya and Brewin (2000) demonstrated that hemicellulose, pectin, callose, and arabinogalactan proteins (AGPs) are found in the walls of transfer cells of pea root nodules.

In some trichomes of the nectaries of L. kamtschatica, cell walls were observed with protuberances developed to different degrees, and in some places their absence was noted. In the study of the septal nectaries of Aloe and Gasteria, S ch ne p f and Pros s (1976) showed that protuberances being the secondary cell wall of the epidermis develop at the nectar pre-secretion phase, and at the post-secretion phase they become degraded. Thus, it is probable that the trichomes observed by us in the freshly blooming flowers of L. kamtschati$c a$, partially devoid of wall protuberances, were still at the stage of their formation.

In the lower-situated lateral portions of the trichomes of the L. kamtschatica nectary, we observed a strong degree of cutinisation of the evenly thickened walls, which may constitute a barrier to secreted nectar whose secretion takes place through the wall fragments with protuberances located in the upper portion of the trichomes from which the cuticle detaches at the time of secretion.

The strongly cutinised lateral wall in the unicellular glandular hairs of nectaries is also described by Fahn (1979, 2000). Lignification or complete cutinisation of the lateral walls of the stalk cells in the pluricellular trichomes of the nectaries were observed by Gunning and Hughes (1976) in Abutilon, $\mathrm{S}$ a w i d i s et. al. (1987) in Hibiscus rosa-sinensis, and
D a v i s et al. (1988) in Vicia faba. According to certain authors ( $\mathrm{N} \mathrm{e} \mathrm{p} \mathrm{i} \mathrm{,} \mathrm{2007),} \mathrm{such} \mathrm{a} \mathrm{wall} \mathrm{structure} \mathrm{in} \mathrm{the} \mathrm{plu-}$ ricellular trichomes enables apoplastic transfer of nectar. On the other hand, Z e $11 \mathrm{n}$ ig et al. (1991) proved that the lipid material accumulated in the lateral walls of the stalk cells of the trichomes in Abutilon does not form an apoplastic barrier for nectar.

At the nectar secretion phase in L. kamtschatica, osmophilic material was found in the pleomorphic tubules of the plastids. However, no starch grains were found in them. Fahn and Rachmilevitz (1970) observed starch grains in the plastids of the glandular trichomes of the L. japonica nectaries only at early stages of their development.

The trichomes and papillae found in the epidermis of the nectary of L. kamtschatica form a large very surface area for nectar secretion, what explains the quick appearance of large amounts of secretion inside the spur and corolla tube already at the beginning of flowering. B o ż e k and W i e n i a r s ka (2006) demonstrated that one flower of L. kamtschatica secrets, on the average, $6.65 \mathrm{mg}$ of nectar (from $3.35 \mathrm{up}$ to $12.16 \mathrm{mg}$ ) over several days of its life. Our study shows that both the trichomes and papillae participate in secretory processes. However, these cells of epidermis clearly differ in their size, the structure of the cell wall and plastids.

\section{REFERENCES}

Bernardello G., 2007. A systematic survey of floral nectaries. [In:] Nectaries and nectar. S. W. Nicolson, Nepi M., E. Pacini (eds.), Springer, Dordrecht.

Bożek M., 2007. Pollen productivity and morphology of pollen grains in two cultivars of honeyberry (Lonicera kamtschatica (Sevast.) Pojark.) Acta Agrobot. 60 (1): 73-77.

Bożek M., Wieniarska J., 2006. Biologia kwitnienia i wydajność cukrowa kwiatów dwóch odmian Lonicera kamtschatica (Sevast.) Pojark. / Biology of flowering and sugar yield of flowers of two varieties of Lonicera kamtschatica (Sevast.) Pojark. Acta Agrobot. 59 (1): 177-182.

Bugała W., 2000. Drzewa i krzewy. PWRiL, Warszawa.

Dahiya P., Brewin N. J., 2000. Immunogold localization of callose and other cell wall components in pea nodule transfer cells. Protoplasma, 214: 210-218.

Davis A. R., Peters on R. L., Shuel R. W., 1988. Vasculature and ultrastructure of the floral and stipular nectaries of Vicia faba (Leguminosae). Can. J. Bot. 66: 1435-1448.

Esau K., 1973. Anatomia roślin. PWRiL, Warszawa.

Fahn A., 1953. The topography of the nectary in the flower and its phylogenetical trend. Phytomorphology, 3: 424-426.

Fahn A., 1979. Ultrastructure of nectaries in relation to nectar secretion. Am. J. Bot. 66: 977-985.

Fahn A., 2000. Structure and function of secretory cells. Adv. Bot. Res. 31: 37-75.

Fahn A., Rachmilevitz T., 1970. Ultrastructure and nectar secretion in Lonicera japonica. [In:] New research in 
plant anatomy. Suppl. J. Linn. Soc. N. K. B. Robson, D. F. Cutler, M. Gregory (eds.), Academic Press, London.

Fahn A., Rachmilevitz T., 1975. An autoradiographical study of nectar secretion in Lonicera japonica Thunb. Ann. Bot. 39: 975-976.

Gunning B. E. S., Pate J. S., 1974. Transfer cells. [In:] Dynamic aspects of plant ultrastructure. A. W. Robards (ed.).

Gunning B. E. S., Hughes J. E., 1976. Quantitative assessment of symplastic transport of pre-nectar into the trichomes of Abutilon Nectaries. Aust. J. Plant Physiol. 3: 619-37.

Kawe cki Z., 2005. Owocodajne drzewa i krzewy chłodniejszych stref klimatycznych. / Fruit-bearing trees and shrubs of cooler climatic zones. Wyd. Uniwersytetu WarmińskoMazurskiego, Olsztyn.

Nepi M., 2007. Nectary structure and ultrastructure. [In:] Nectaries and nectar. S. W. Nicolson, M. Nepi., E. Pacini (eds.), Springer, Dordrecht.

Paccini E., Nepi M., 2007. Nectar production and presentation. [In:] Nectaries and nectar. S. W. Nicolson, M. Nepi., E. Pacini, Springer, Dordrecht.

Sawidis T., Eleftheriou E. P., Tsekos I., 1987. The floral nectaries of Hibiscus rosa-sinensis. I. Development of the secretory hairs. Ann. Bot. 59: 643-652.

Schmid R., 1988. Reproductive versus extra-reproductive nectaries - Historical perspective and terminological recommendations. Botanical Review, 54: 179-232.

Schnepf E., Pross E., 1976. Differentiation and redifferentiation of a transfer cell: Development of septal nectaries of Aloe and Gasteria. Protoplasma, 89: 105-115.

Smets E., 1986. Localization and systematic importance of the floral nectaries in the Magnoliatae (Dicotyledons). Bull. Jard. Bot. Nat. Belg. 56: 51-76.
Szweykowska A., Szweykowski J. (red), 2003. Słownik botaniczny. Wiedza Powszechna, Warszawa.

Vogel S., 1977. Nectaries and their ecological significant. Apidologie, 8: 321-336.

Zellnig G., Kronestedt-Robards E. C., Robards A. W., 1991. Intercellular permeability in Abutilon nectary trichomes. Protoplasma, 161: 150-159.

\section{Struktura nektarników trichomowych w kwiatach Lonicera kamtschatica (Sevast.) Pojark.}

\section{Streszczenie}

Przy użyciu mikroskopii świetlnej, skaningowej elektronowej i transmisyjnej elektronowej badano strukturę nektarników kwiatowych Lonicera kamtschatica. Tkanki nektarnikowe położone są w dolnej części rurki korony. Stwierdzono, że tkankę sekrecyjną nektarnika stanowiły dwie warstwy wytworów epidermy: krótkie brodawki i około trzy razy dłuższe jednokomórkowe włoski. Pokrywają one doosiową powierzchnię niewielkiej ostrogi.

Wydzielanie nektaru odbywa się przez szczytową część włosków i brodawek. Ściana komórkowa górnej części włoska posiada protuberancje uczestniczące w przenikaniu nektaru do przestrzeni subkutykularnej, która osiaga pokaźne rozmiary. Boczne ściany włosków są wysycone kutyną. Brodawki mają znacznie grubsze ściany niż włoski. W brodawkach nie występują protuberancje ścian. W przestrzeni subkutykularnej brodawek gromadzi się mniej wydzieliny niż w przypadku włosków. 